\title{
EFEK IMPLANTASI ELEMEN TERNER DAN KUATERNER TERHADAP KETAHANAN OKSIDASI PADUAN TITANIUM ALUMINIUM (TiAl)
}

\author{
Lely Susita RM., Sudjatmoko, Tjipto Sujitno \\ Puslitbang Teknologi Maju - BATAN \\ Jl. Babarsari Kotak Pos 1008, Yogyakarta 55010
}

\begin{abstract}
ABSTRAK
EFEK IMPLANTASI ELEMEN TERNER DAN KUARTENER TERHADAP KETAHANAN OKSIDASI PADUAN TITANIUM ALUMINIUM (TiAl). Tujuan utama penelitian ini adalah menyelidiki efek implantasi ion Si dan Mo serta menentukan kondisi optimum implantasi elemen reaktif tersebut untuk meningkatkan ketahanan oksidasi paduan biner TiAl dan paduan terner TiAl-Si serta TiAl-Mo selama siklus termal. Untuk maksud tersebut ion Si diimplantasikan pada paduan biner TiAl dan terner TiAl-Mo pada energi $45 \mathrm{keV}$, sedangkan ion Mo diimplantasikan pada paduan biner TiAl dan terner TiAl-Si pada energi $100 \mathrm{keV}$. Selama proses implantasi, arus ion dibuat tetap yaitu sebesar $10 \mu \mathrm{A}$, sedangkan dosis ion divariasi yaitu $1,5 \times 10^{15} \mathrm{ion} / \mathrm{cm}^{2}, 3,0 \times 10^{15} \mathrm{ion} / \mathrm{cm}^{2}$, dan $4,5 \times 10^{15} \mathrm{ion} / \mathrm{cm}^{2}$. Untuk pengujian dengan kondisi siklus termal, maka selanjutnya setiap cuplikan dioksidasi pada temperatur $800^{\circ} \mathrm{C}$ dengan waktu pemanasan selama 5 jam dan pendinginan pada suhu kamar selama 19 jam. Proses oksidasi dilakukan dalam lingkungan oksigen, dan kondisi ini diperoleh dengan cara mengalirkan gas oksigen ke dalam tabung oksidasi dengan laju alir $0.021 \mathrm{cc} / \mathrm{min}$, dan tekanan $2 \mathrm{kgf} / \mathrm{cm}^{2}$. Laju oksidasi ditentukan dari pengukuran perubahan berat cuplikan sebelum dan sesudah dioksidasi. Berdasarkan analisis data hasil penelitian menunjukkan bahwa implantasi ion Si pada paduan biner TiAl dan implantasi ion Mo pada paduan biner TiAL dan terner TiAl-Si mampu meningkatkan ketahanan oksidasi paduan tersebut selama siklus termal pada temperatur $800^{\circ} \mathrm{C}$. Sedangkan implantasi ion Si pada paduan terner TiAl-Mo cenderung menurunkan ketahanan oksidasinya. Kondisi optimum implantasi ion Si untuk meningkatkan ketahanan oksidasi paduan biner TiAL selama siklus termal dicapai pada dosis ion $4,5 \times 10^{15} \mathrm{ion} / \mathrm{cm}^{2}$. Sedangkan kondisi optimum implantasi ion Mo untuk meningkatkan ketahanan oksidasi paduan biner TiAl dan terner TiAl-Si selama siklus termal dicapai pada dosis $1,5 \times 10^{15} \mathrm{ion} / \mathrm{cm}^{2}$
\end{abstract}

\begin{abstract}
EFFECT OF TERNER AND QUARTENER ELEMENTS IMPLANTATION ON THE OXIDATION RESISTANCE OF TITANIUM ALUMINIUM (TiAL) ALLOYS. The main objective of this research is to investigate the effect of Si and Mo ion implantation on the oxidation resistance of Titanium Aluminium (TiAl) alloys and also to determine the optimum conditions of the implantation for improving the oxidation resistance of TiAl biner alloy and TiAl-Si \& TiAl-Mo terner alloys during cyclus thermal. For the purpose, Si ion was implanted into TiAl biner alloy and TiAl-Mo terner alloy at energy $45 \mathrm{keV}$, while the Mo ion was implanted into TiAl biner alloy and TiAl-Si terner alloys at energy $100 \mathrm{keV}$. During the implantation, the beam current was keept constant, i.e. $10 \mu \mathrm{A}$, while the ion dose was varied i.e. $1.5 \times 10^{15} \mathrm{ion} / \mathrm{cm}^{2}, 3.0 \times 10^{15} \mathrm{ion} / \mathrm{cm}^{2}$, and $4.5 \times 10^{15} \mathrm{ion} / \mathrm{cm}^{2}$. After this process, the samples were oxidized at $800^{\circ} \mathrm{C}$ for 5 hours and cooled in room temperature for 19 hours. The oxidation process was carried out in oxygen environment, for the purpose the oxidation tube was introduced by oxygen gas at 0.021 $\mathrm{cc} / \mathrm{min}$, and at $2 \mathrm{kgf} / \mathrm{cm}^{2}$. The oxidation rate was determined by measuring the weight/mass changing before and after oxidation process. Based on the results, it can be showed that the implantation of Si ion into TiAl biner alloys and Mo ion into TiAl biner alloys \& TiAl-Si terner alloys can improve the oxidation resistance of the alloys during cyclus thermal. While the implantation of Mo ion into TiAl-Mo terner alloys trend to decrease the oxidation resistance. The optimum conditions of the implantation for improving the oxidation resistance was achieved at ion dose $4.5 \times 10^{15}$ ion/ $\mathrm{cm}^{2}$. While the optimum conditions for implantation of Mo into TiAl biner alloy and TiAl-Si terner alloys during cyclus thermal was achieved at ion dose $1.5 \times 10^{15} \mathrm{ion} / \mathrm{cm}^{2}$
\end{abstract}




\section{PENDAHULUAN}

$\mathrm{P}$ aduan super nikel merupakan material yang tahan terhadap operasi suhu tinggi, namun material tersebut sangat mahal.

Dengan demikian para peneliti berlomba mencari material alternatif yang dapat mengganti fungsi paduan super nikel tersebut. Diantara material alternatif yang telah ditemukan dan mampu mengganti fungsi paduan super nikel adalah paduan titanium aluminium (TiAl). Dibandingkan dengan paduan super nikel, paduan TiAl ini lebih ringan dengan densitas 3,8 $\mathrm{gr} / \mathrm{cm}^{3}$, dan mempunyai kekuatan mekanik hampir sama. Kelemahan utama paduan TiAl untuk aplikasi pada temperatur tinggi adalah tidak tahan terhadap operasi di atas temperatur $700^{\circ} \mathrm{C}^{(1)}$

Untuk mengatasi masalah tersebut beberapa peneliti telah menemukan bahwa dengan penambahan elemen-elemen reaktif seperti Al, Cr, Mn, Mo, Nb, Pt, Rh, Si, Ta, W dan Y pada jumlah tertentu (berkisar anatara $0,1 \%$ hingga $1 \%$ massa) dan dapat terdistribusi secara merata pada kedalaman kurang dari $500 \AA \AA$ akan mampu meningkatkan ketahanan oksidasi paduan TiAl di atas temperatur $700^{\circ} \mathrm{C} .^{(2)}$

Ketahanan material terhadap operasi suhu tinggi adalah dikarenakan selama beroperasi mampu membentuk lapisan oksida pelindung (protective oxide layer) seperti oksida aluminium $\left(\mathrm{Al}_{2} \mathrm{O}_{3}\right)$, oksida silikon $\left(\mathrm{SiO}_{2}\right)$ dan oksida molybdenum $\left(\mathrm{MoO}_{2} / \mathrm{MoO}_{3}\right)$. Oksida yang terbentuk ini mampu melindungi komponen logam pada suhu tinggi karena laju pertumbuhan oksidanya lambat, volatilitas rendah dan stabilitas termodinamikanya tinggi. ${ }^{(3-5)}$

Meskipun oksida yang terbentuk pada permukaan material bersifat protektif, namun karena adanya stress dalam pertumbuhan oksidanya sendiri, strain yang dihasilkan oleh peristiwa mekanis didalam komponen pada saat diperbaiki, ataupun stress yang muncul dari proses siklus termal (thermal cycling) akibat perbedaan koefisien ekspansi termal antara oksida dengan material induknya (base material), maka lapisan proteksi yang terbentuk cenderung mengelupas. Selain itu, jika elemen-elemen paduan terlalu larut dan material teroksidasi secara internal maka efektivitasnya dalam membentuk lapisan pelindung akan berkurang. ${ }^{(6)}$

Masalah pengelupasan lapisan oksida ini bisa menjadi masalah yang serius jika tidak ditangani dengan baik. Dengan demikian perlu dilakukan pengendalian secara preventif untuk menghambat pengelupasan tersebut. Hal ini akan lebih baik dari pada memperbaiki material secara kuratif yang biayanya akan jauh lebih besar.

Peningkatan ketahanan oksidasi suatu material memerlukan suatu rekayasa permukaan karena oksidasi biasanya dimulai dari permukaan material. Salah satu metode yang digunakan untuk tujuan tersebut adalah teknik implantasi ion, yaitu suatu teknik untuk menambahkan atau mengimplantasikan atom asing ke dalam material target. Kelebihan teknik implantasi ion untuk surface treatment dibandingkan dengan teknik konvensional antara lain kedalaman dan dosis ion dapat dikendalikan dengan akurat, prosesnya cepat (dalam orde menit), tidak ada thermal stress sebab tidak melibatkan besaran panas dan tidak terjadi perubahan dimensi (distorsi) yang berarti. Pada teknik implantasi ion, parameter yang berpengaruh terhadap hasil akhir adalah nomor dan massa atom sasaran, nomor dan massa atom asing (jenis ion), energi dan dosis ion. ${ }^{(7-8)}$

Berdasarkan alasan tersebut, maka akan dilakukan penelitian tentang efek implantasi elemen reaktif silikon dan molybdenum untuk peningkatan ketahanan oksidasi paduan biner TiAl serta terner TiAl-Mo dan TiAl-Si di atas temperatur $700^{\circ} \mathrm{C}$. 


\section{TATA KERJA DAN PERCOBAAN}

Tata kerja dalam penelitian ini mencakup preparasi cuplikan, teknik eksperimen dan uji oksidasi.

\section{Preparasi cuplikan}

Cuplikan yang diimplantasi dengan elemen reaktif silikon dan molybdenum adalah lembaran paduan TiAl yang sudah cukup halus permukaannya. Lembaran tersebut kemudian dipotong menjadi cuplikan berbentuk kepingan dengan ukuran $(1 \times 1) \mathrm{cm}$. Untuk menghilangkan kotoran yang masih melekat, cuplikan dicuci menggunakan mesin pembersih ultrasonik yang berisi alkohol dan kemudian dikeringkan.

\section{Teknik eksperimen}

Ada dua besaran yang sangat penting dari hasil implantasi suatu ion pada bahan, yaitu kedalaman penetrasi ion pada permukaan bahan dan distribusi konsentrasi ion yang diimplantasikan. Parameter kedalamanan penetrasi ion adalah jenis ion dan energi ion yang diimplantasikan serta jenis bahan. Sedangkan parameter yang mempengaruhi distribusi konsentrasi ion adalah arus ion dan lamanya proses implantasi ion berlangsung.

Kedalaman penetrasi ion berhubungan dengan jangkau ion rata-rata dalam bahan, secara matematis dapat dituliskan sebagai berikut,

$$
R=\frac{0,6 E\left[Z_{1}^{2 / 3}+Z_{2}^{2 / 3}\right]^{1 / 2}\left(M_{1}+M_{2}\right) M_{2}}{\rho Z_{1} Z_{2} M_{1}}
$$

dimana $\mathrm{E}$ adalah energi ion yang datang, $\mathrm{M}_{1}$ adalah massa ion dan $\mathrm{Z}_{1}$ adalah nomer atom ion, $\mathrm{M}_{2}$ adalah nomer massa bahan dan $\mathrm{Z}_{2}$ adalah nomer atom bahan, dan $\rho$ adalah rapat bahan. Proyeksi jangkau ion pada arah datangnya ion mula-mula disebut jangkau terproyeksi $\mathrm{R}_{\mathrm{p}}$. Korelasi antara jangkau rata-rata $\mathrm{R}$ dengan $\mathrm{R}_{\mathrm{p}}$ dapat dituliskan,

$$
\frac{R}{R_{p}}=\frac{1}{4}\left[(5+A) \frac{(1+A)}{2 \sqrt{5}} \arccos \frac{1-A}{1+A}-1-3 A\right]
$$

dengan $\mathrm{A}=\mathrm{M}_{2} / \mathrm{M}_{1}$. Apabila nilai $\mathrm{A} \leq 1$, maka persamaan di atas dapat disederhanakan menjadi,

$$
\frac{R}{R_{p}}=1+\frac{M_{2}}{3 M_{1}}=1+\frac{1}{3} A
$$

Perpindahan energi setiap tumbukan antara ion dengan atom-atom bahan bersifat acak, sehingga suatu ion dengan energi mula-mula yang sama akan mempunyai jangkau ion terproyeksi yang berbeda. Karena itu terjadi simpangan rata-rata distribusi jangkau ion terproyeksi yang menimbulkan deviasi standar $\sigma \mathrm{R}_{\mathrm{p}}$. Distribusi konsentrasi ion dapat didekati dengan distribusi statistik Gauss, dan konsentrasi ion dopan pada kedalaman $\mathrm{x}$ dapat dituliskan sebagai berikut,

$$
N(x)=\frac{C_{s}}{\sqrt{2 \sigma R_{p}}} \exp \left[-\frac{\left(x-R_{p}\right)^{2}}{2 \sigma R_{p}^{2}}\right]
$$

dimana $\mathrm{C}_{\mathrm{s}}$ adalah dosis ion dopan yang diimplantasikan pada bahan, besarnya sebagai fungsi dari arus berkas ion dan waktu proses implantasi ion.

$$
C_{s}=\frac{1}{e A} \int i . d t
$$

dimana e adalah muatan ion, A adalah luas permukaan bahan, i adalah arus berkas ion, dan t adalah waktu proses implantasi.

Berdasarkan perumusan-perumusan di atas dilakukan eksperimen dengan variasi parameter sebagai berikut

a) Variasi jenis ion dopan untuk memperoleh kondisi ketahanan oksidasi dari cuplikan.

b) Variasi dosis atau konsentrasi ion untuk memperoleh ketahanan oksidasi dari cuplikan yang paling optimum

Dalam penelitian ini dilakukan implantasi ion dopan silikon dan molybdenum pada cuplikan TiAl, serta variasi dosis ion sebesar $1,5 \times 10^{15} \mathrm{ion} / \mathrm{cm}^{2}$, 
$3,0 \times 10^{15} \mathrm{ion} / \mathrm{cm}^{2}$ dan $4,5 \times 10^{15} \mathrm{ion} / \mathrm{cm}^{2}$ pada energi $45 \mathrm{keV}$ untuk ion silikon dan energi $100 \mathrm{keV}$ untuk ion molybdenum.

\section{Uji oksidasi}

Uji oksidasi dari cuplikan TiAl berkenaan dengan pemakaian TiAl sebagai material struktural pada temperatur menengah $\left(600{ }^{0} \mathrm{C}-800{ }^{0} \mathrm{C}\right)$. Uji oksidasi dilakukan dalam media oksigen kering selama 5 siklus termal dengan waktu pemanasan setiap siklus termal 5 jam pada temperatur $800{ }^{0} \mathrm{C}$ dan pendinginan 19 jam pada temperatur kamar. Selama uji siklus termal, cuplikan yang telah dimasukkan ke dalam tabung dialiri dengan gas oksigen dengan laju aliran oksigen sebesar 0,021 $\mathrm{cc} /$ menit dan tekanan oksigen $2 \mathrm{kgf} / \mathrm{cm}^{2}$. Adanya oksigen di lingkungan sekitar cuplikan menyebabkan terjadinya proses oksidasi pada temperatur $800{ }^{0} \mathrm{C}$. Selama proses oksidasi berlangsung pada cuplikan TiAl, probabilitas terbesar terjadinya oksidasi adalah antara silikon dan oksigen membentuk oksida silikon $\left(\mathrm{SiO}_{2}\right)$ serta antara molybdenum dan oksigen membentuk oksida molybdenum $\left(\mathrm{MoO}_{2} / \mathrm{MoO}_{3}\right)$ karena oksidasi dimulai dari permukaan cuplikan yang banyak mengandung kedua elemen reaktif tersebut. Proses oksidasi ini dapat diamati berdasarkan perubahan berat cuplikan selama siklus termal. Berdasarkan eksperimen di atas dibuat grafik hubungan antara waktu oksidasi terhadap perubahan berat selama 5 siklus termal dengan waktu pemanasan setiap siklus 5 jam dan waktu pendinginan 19 jam, baik untuk cuplikan yang belum maupun yang telah diimplantasi. Dengan grafik tersebut diharapkan akan diperoleh kondisi ketahanan oksidasi yang paling optimum.

\section{HASIL DAN PEMBAHASAN}

\section{A. Hasil Penelitian}

Hasil uji siklus termal dalam lingkungan oksigen kering pada temperatur $800{ }^{0} \mathrm{C}$ selama 5 siklus termal dengan waktu pemanasan setiap siklus termal 5 jam dan waktu pendinginan 19 jam untuk paduan biner TiAl serta paduan terner TiAl-Mo dan TiAl-Si yang diimplantasi dengan ion Si dan Mo untuk berbagai variasi dosis ion disajikan pada Gambar 1, 2, 3, 4, 5, 6 dan 7.

\section{Efek Implantasi Ion $\mathrm{Si}$ terhadap Ketahanan Oksidasi Paduan Biner TiAl}

Ion silikon yang diimplantasikan ke permukaan TiAl divariasi dengan dosis ion $1,5 \times 10^{15} \mathrm{ion} / \mathrm{cm}^{2}, 3,0 \times 10^{15} \mathrm{ion} / \mathrm{cm}^{2}$, dan $4,5 \times 10^{15} \mathrm{ion} / \mathrm{cm}^{2}$. Dari data hasil penelitian menunjukkan bahwa penambahan elemen reaktif Si dapat meningkatkan laju oksidasi paduan biner TiAl.

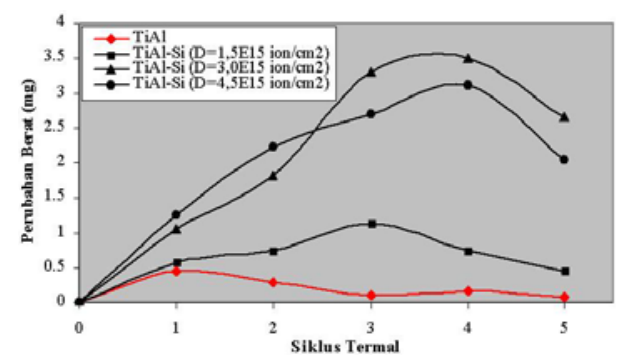

Gambar 1. Laju oksidasi siklus termal paduan biner TiAl dan terner TiAl-Si hasil implantasi pada dosis ion $1,5 \times 10^{15}$ ion $/ \mathrm{cm}^{2}, 3,0 \times 10^{15}$ ion $/ \mathrm{cm}^{2}$ dan $4,5 \times 10^{15}$ ion $/ \mathrm{cm}^{2}$.

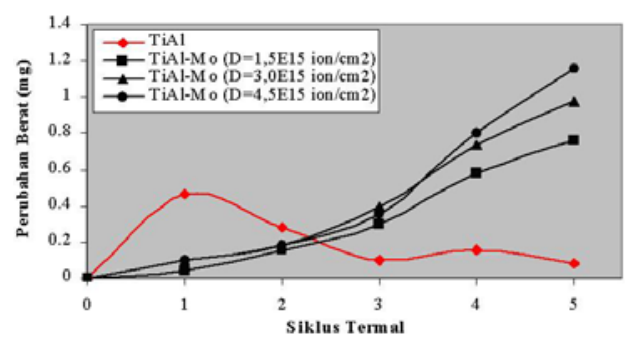

Gambar 2. Laju oksidasi siklus termal paduan biner TiAl dan terner TiAl-Mo hasil implantasi pada dosis ion $1,5 \times 10^{15}$ ion $/ \mathrm{cm}^{2}, 3,0 \times 10^{15} \mathrm{ion} / \mathrm{cm}^{2}$ dan $4,5 \times 10^{15}$ ion $/ \mathrm{cm}^{2}$. 


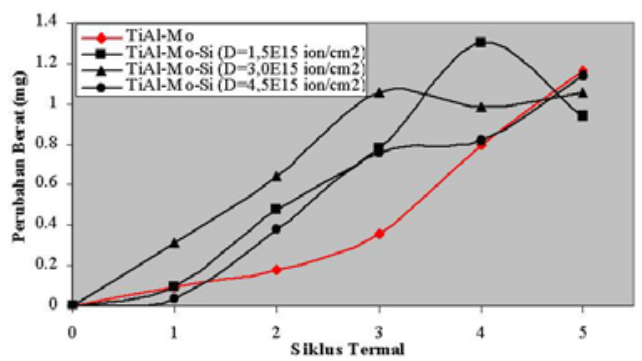

Gambar 3. Laju oksidasi siklus termal paduan terner TiAl-Mo dan kuartener TiAl-Mo-Si hasil implantasi pada dosis ion $1,5 \times 10^{15}$ ion $/ \mathrm{cm}^{2}, \quad 3,0 \times 10^{15}$ ion $/ \mathrm{cm}^{2}$ dan $4,5 \times 10^{15}$ ion $/ \mathrm{cm}^{2}$.

Profil laju oksidasi paduan biner TiAl yang diimplantasi dengan ion $\mathrm{Si}$ dan yang tidak diimplantasi ditunjukkan oleh Gambar 1. Seperti yang terlihat pada profil tersebut, laju oksidasi paduan TiAl yang tidak diimplantasi pada awal oksidasi hingga siklus yang pertama menunjukkan profil yang sama dengan laju oksidasi yang diimplantasi dengan ion Si, yaitu berbentuk parabolik. Namun ketika waktu oksidasi lebih dari satu siklus, laju oksidasi paduan TiAl yang tidak diimplantasi turun karena adannya pengelupasan oksida yang telah terbentuk. Pengelupasan ini berlanjut sampai pada akhir siklus yang ketiga. Pada siklus yang keempat, laju oksidasinya mengalami peningkatan dan akhirnya turun kembali karena terjadi pengelupasan oksida yang telah terbentuk. Pengelupasan ini berlanjut sampai pada akhir siklus, yaitu siklus yang kelima. Hal ini berbeda dengan paduan TiAl yang diimplantasi dengan ion Si, mengalami penurunan laju oksidasi karena adanya pengelupasan oksida setelah siklus yang ketiga.

Pada paduan TiAl yang diimplantasi dengan ion Si pada dosis $1,5 \times 10^{15}$ ion $/ \mathrm{cm}^{2}$, profil laju oksidasi dari awal oksidasi sampai dengan siklus yang ketiga berbentuk parabolik. Ketika waktu oksidasi lebih dari 3 siklus, laju oksidasi menurun karena adanya pengelupasan oksida yang telah terbentuk.
Pengelupasan ini berlanjut sampai pada akhir waktu oksidasi.

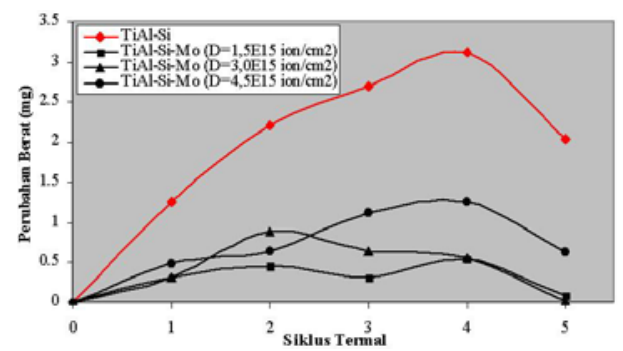

Gambar 4. Laju oksidasi siklus termal paduan terner TiAl-Si dan kuartener TiAl-Si-Mo hasil implantasi pada dosis ion $1,5 \times 10^{15}$ ion $/ \mathrm{cm}^{2}, 3,0 \times 10^{15}$ ion $/ \mathrm{cm}^{2}$ dan $4,5 \times 10^{15}$ ion $/ \mathrm{cm}^{2}$.

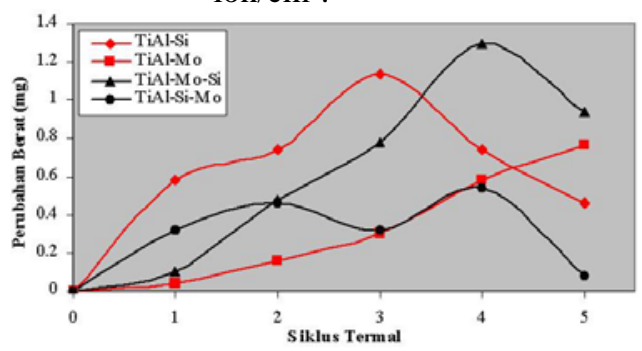

Gambar 5. Laju oksidasi siklus termal paduan terner TiAl-Si dan TiAl-Mo serta kuartener TiAl-Mo-Si dan TiAl-SiMo hasil implantasi pada

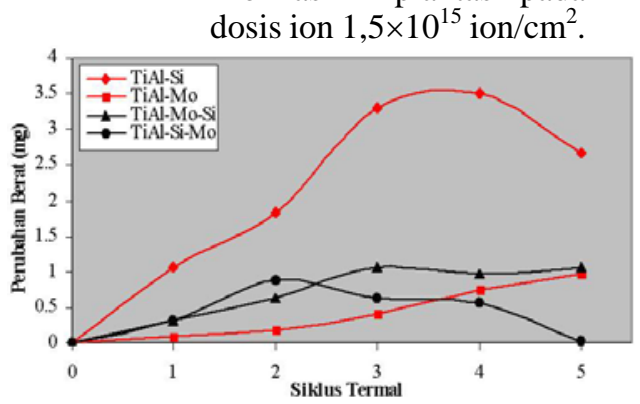

Gambar 6. Laju oksidasi siklus termal paduan terner TiAl-Si dan TiAl-Mo serta kuartener TiAl-Mo-Si dan TiAl-Si-Mo hasil implantasi pada dosis ion $3,0 \times 10^{15} \mathrm{ion} / \mathrm{cm}^{2}$. 


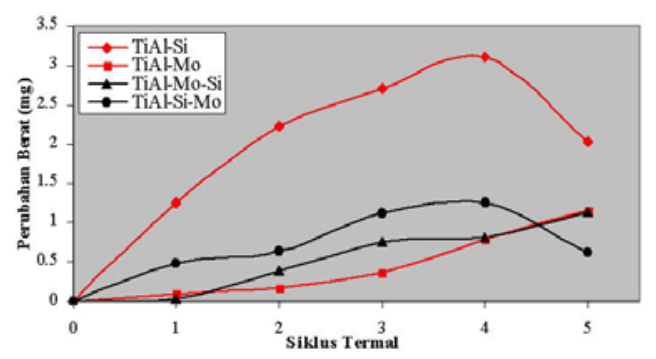

Gambar 7. Laju oksidasi siklus termal paduan terner TiAl-Si dan TiAl-Mo serta kuartener TiAlMo-Si dan TiAl-Si-Mo hasil implantasi pada dosis ion $4,5 \times 10^{15} \mathrm{ion} / \mathrm{cm}^{2}$.

Pada paduan TiAl yang diimplantasi ion Si dengan dosis 3,0 x $10^{15} \mathrm{ion} / \mathrm{cm}^{2}$, laju oksidasinya cenderung meningkat dari awal oksidasi sampai pada siklus yang keempat. Setelah itu, laju oksidasinya turun. Sedangkan untuk dosis $4,5 \times 10^{15} \mathrm{ion} / \mathrm{cm}^{2}$, laju oksidasinya meningkat dari awal oksidasi hingga akhir siklus yang keempat. Setelah itu, laju oksidasi menjadi turun. Hal ini menunjukkan bahwa pertumbuhan oksidasi- nya telah mencapai maksimal pada akhir siklus yang keempat.

Secara umum implantasi ion $\mathrm{Si}$ dengan dosis ion $1,5 \times 10^{15} \mathrm{ion} / \mathrm{cm}^{2}, 3.0 \mathrm{x}$ $10^{15} \mathrm{ion} / \mathrm{cm}^{2}$ dan $4,5 \times 10^{15} \mathrm{ion} / \mathrm{cm}^{2}$ pada paduan TiAl justru meningkatkan laju oksidasi paduan TiAl. Namun demikian ketahanan oksidasi paduan TiAl yang diimplantasi masih lebih baik dari pada paduan TiAl yang tidak diimplantasi. Hal ini dapat ditunjukkan dengan umur pemakaian terhadap pengelupasan oksida yang terbentuk lebih lama.

\section{Efek Implantasi Ion Si Terhadap Ketahanan Oksidasi Paduan Terner TiAl-Mo}

Dari hasil uji oksidasi terlihat bahwa secara umum dengan adanya penambahan elemen reaktif Si pada permukaan TiAl yang telah diimplantasi dengan ion Mo pada dosis ion $4,5 \times 10^{15}$ ion $/ \mathrm{cm}^{2}$ justru meningkatkan laju oksidasinya.
Profil laju oksidasi paduan terner TiAl-Mo yang tidak diimplantasi dan yang diimplantasi dengan ion Si pada dosis ion 1,5 x $10^{15} \mathrm{ion} / \mathrm{cm}^{2}, 3,0 \times 10^{15} \mathrm{ion} / \mathrm{cm}^{2}$, dan $4,5 \mathrm{x}$ $10^{15}$ ion $/ \mathrm{cm}^{2}$ ditunjukkan oleh Gambar 3. Pada Gambar 3 terlihat bahwa untuk awal oksidasi sampai pada siklus yang ketiga mempunyai profil yang sama, yaitu berbentuk parabolik. Namun ketika waktu oksidasi lebih dari empat siklus ternyata untuk paduan TiAl-Mo yang diimplantasi dengan dosis ion $1,5 \times 10^{15} \mathrm{ion} / \mathrm{cm}^{2}$, laju oksidasinya turun. Sedangkan paduan TiAl-Mo yang diimplanta- si pada dosis ion $3,0 \times 10^{15} \mathrm{ion} / \mathrm{cm}^{2}$, laju oksidasinya turun setelah siklus yang ketiga. Penurunan oksidasi ini disebabkan adanya pengelupasan oksida yang telah terbentuk, kemudian oksida tersebut tumbuh lagi pada siklus yang kelima sampai pada akhir waktu oksidasi. Hal ini mengindikasikan bahwa daya lekat oksida yang terbentuk belum begitu melekat dengan kuat. Berbeda halnya dengan paduan TiAl-Mo yang tidak diimplantasi dan yang diimplantasi dengan ion Si pada dosis ion $4,5 \times 10^{15} \mathrm{ion} / \mathrm{cm}^{2}$. Pada paduan ini, oksida yang terbentuk sudah mempunyai daya lekat yang tinggi, hal ini ditunjukkan dengan tidak terjadinya pengelupasan oksida yang telah terbentuk selama rentang waktu oksidasi 5 siklus.

Dari uraian di atas, terlihat bahwa secara umum penambahan elemen reaktif Si pada paduan TiAl-Mo tidak efektif untuk meningkatkan ketahanan oksidasi tetapi cenderung menurunkan ketahanan oksidasi. Hal ini dilihat dari peningkatan laju oksidasi yang semakin besar dan berkurangnya umur pemakaian terhadap pengelupasan.

\section{Efek Implantasi Ion Mo terhadap Ketahanan Oksidasi Paduan Biner TiAl}

Dari hasil uji oksidasi menunjukkan bahwa laju oksidasi dipengaruhi oleh implantasi elemen reaktif Mo pada permukaan paduan biner TiAl. Semakin 
besar dosis ion Mo maka semakin besar laju oksidasinya.

Laju oksidasi paduan TiAl yang tidak diimplantasi dan yang diimplantasi dengan ion Mo mempunyai profil yang sama yaitu berbentuk parabolik. Pada Gambar 2 terlihat adanya kecenderungan untuk terbentuknya oksidasi dengan daya lekat (adherence) yang tinggi sehingga mampu menghalangi proses oksidasi selanjutnya. Pada rentang waktu oksidasi dari awal oksidasi sampai dengan siklus yang keempat, oksidasi yang terbentuk terus bertambah besar (oksida yang terbentuk semakin menebal). Namun ketika proses oksidasi lebih dari siklus yang keempat oksida yang terbentuk mulai menipis karena difusi ion Mo menuju permukaan oksida dihalangi oleh lapisan oksida yang telah terbentuk sebelumnya. Begitu juga yang terjadi dengan atom-atom oksigen meskipun atom-atom menangkap elektron untuk membentuk ion oksigen, laju difusinya dalam melewati permukaan oksida untuk bergabung dengan ion-ion Mo dalam membentuk oksida molybdenum terhalangi oleh oksida sebelumnya. Akibat adanya halangan ini, probabilitas ion-ion Mo dan oksigen untuk bereaksi menjadi kecil sehingga laju pembentukan oksida juga semakin kecil. Dalam rentang 5 siklus termal tidak terjadi pengelupasan oksida untuk semua dosis seperti yang ditunjukkan pada Gambar 2. Hal ini menunjukkan bahwa lapisan oksida pelindung yang terbentuk mempunyai daya lekat yang kuat sehingga mampu menghalangi proses oksidasi selanjutnya.

Secara umum penambahan ion Mo pada paduan TiAl mampu meningkatkan ketahanan oksidasi paduan TiAl. Hal ini ditunjukkan adanya penurunan laju oksidasi dan umur pemakaian yang lebih lama. Kondisi optimum dari penambahan ion Mo dalam meningkatkan ketahanan oksidasi paduan TiAl selama siklus termal dicapai pada dosis ion $1,5 \times 10^{15} \mathrm{ion} / \mathrm{cm}^{2}$ karena pada dosis ini laju oksidasinya paling rendah.

\section{Efek Implantasi Ion Mo Terhadap Ketahanan Oksidasi Paduan Terner TiAl-Si}

Dari hasil uji oksidasi menunjukkan bahwa penambahan elemen reaktif Mo pada permukaan TiAl yang telah diimplantasi dengan ion Si dengan dosis ion 4,5 x $10^{15}$ ion $/ \mathrm{cm}^{2}$ mampu menurunkan laju oksidasi. Semakin kecil dosis ion Mo semakin besar pula penurunan laju oksidasinya.

Profil laju oksidasi paduan TiAl-Si yang tidak diimplantasi dan yang diimplantasi dengan ion Mo ditunjukkan pada Gambar 4. Dari Gambar 4 terlihat bahwa pada awal oksidasi sampai siklus yang kedua menunjukkan profil yang sama, yaitu berbentuk parabolik. Namun ketika waktu oksidasi lebih dari dua siklus, ternyata untuk paduan TiAl-Si yang diimplantasi pada dosis ion $1,5 \times 10^{15} \mathrm{ion} / \mathrm{cm}^{2}$ dan $3,0 \mathrm{x}$ $10^{15} \mathrm{ion} / \mathrm{cm}^{2}$ mengalami penurunan laju oksidasi. Untuk dosis ion $1,5 \times 10^{15} \mathrm{ion} / \mathrm{cm}^{2}$ oksida terbentuk lagi pada siklus yang keempat dan akhirnya terjadi pengelupasan lagi dan cenderung mengelupas terus. Pada dosis ion 3,0 x $10^{15} \mathrm{ion} / \mathrm{cm}^{2}$ pengelupasaan berlanjut sampai pada akhir waktu oksidasi, yaitu siklus yang kelima. Hal ini menunjukkan bahwa oksida yang terbentuk belum mempunyai daya lekat yang kuat. Hal ini mungkin disebabkan distribusinya belum merata.

Berbeda halnya dengan paduan TiAl-Si yang tidak diimplantasi dan yang diimplantasi dengan ion Mo pada dosis ion $4,5 \times 10^{15} \mathrm{ion} / \mathrm{cm}^{2}$. Pada paduan ini, proses pengelupasan baru terjadi pada siklus yang kelima. Hal ini menunjukkan bahwa paduan TiAl-Si yang tidak diimplantasi dan yang diimplantasi dengan ion Mo pada dosis ion $4,5 \times 10^{15} \mathrm{ion} / \mathrm{cm}^{2}$ mampu menghasilkan oksida yang mempunyai daya lekat yang kuat dibandingkan dengan paduan TiAl-Si yang diimplantasi dengan ion Mo pada dosis ion $1,5 \times 10^{15} \mathrm{ion} / \mathrm{cm}^{2}$ dan $3,0 \times 10^{15} \mathrm{ion} / \mathrm{cm}^{2}$.

Dapat disimpulkan bahwa penambahan elemen reaktif Mo pada paduan TiAl-Si, dapat meningkatkan ketahanan oksidasinya. 
Kondisi optimum dari penambahan ion Mo dalam meningkatkan ketahanan oksidasi paduan TiAl-Si dicapai pada dosis ion 1,5 $\mathrm{x}$ $10^{15} \mathrm{ion} / \mathrm{cm}^{2}$, karena pada dosis ini laju oksidasinya paling lambat dan selama 5 siklus termal tidak terjadi pengelupasan.

\section{Perbandingan Efek Implantasi Ion Si dan Mo Terhadap Ketahanan Oksidasi Paduan Biner TiAl Serta Paduan Terner TiAl-Mo, dan TiAl-Si}

Implantasi ion $\mathrm{Si}$ dan Mo mampu memberikan kontribusi yang signifikan terhadap perubahan sifat ketahanan oksidasi paduan TiAl, TiAl-Mo, dan TiAl-Si.

Dari hasil uji oksidasi (seperti yang terlihat pada Gambar 5-7) menunjukkan bahwa implantasi ion Si justru meningkatkan laju oksidasi paduan TiAl dan TiAl-Mo, sedangkan implantasi ion Mo mampu menurunkan laju oksidasi paduan TiAl dan TiAl-Si. Kecenderungan ini berhubungan dengan harga potensial ionisasi kedua jenis atom tersebut. Atom Si untuk menjadi kation $\mathrm{Si}^{2+}$ membutuhkan potensial sebesar 16,345 volt, sedangkan atom Mo membutuhkan potensial sebesar 27,16 volt untuk menjadi kation $\mathrm{Mo}^{3+}$. Oleh karena itu, dengan energi yang sama kation $\mathrm{Mo}^{3+}$ yang terbentuk lebih sedikit dibandingkan dengan dengan kation $\mathrm{Si}^{2+}$, sehingga pada waktu oksidasi yang sama, oksida molybdenum $\left(\mathrm{MoO}_{3}\right)$ yang terbentuk juga lebih sedikit dibandingkan dengan oksida silikon $\left(\mathrm{SiO}_{2}\right)$.

Selama siklus termal pada suhu $800{ }^{\circ} \mathrm{C}$, paduan biner TiAl yang diimplantasi dengan ion Si mengalami pengelupasan pada siklus yang kelima, sedangkan paduan biner TiAl yang diimplantasi dengan ion Mo tidak mengalami pengelupasan. Hal ini dipengaruhi oleh nilai panas penguapan (heat evaporation) dari kedua jenis atom tersebut. Atom Si memerlukan kalor sebesar $384,220 \mathrm{~kJ} / \mathrm{mol}$ untuk menguapkan atom-atomnya, sedangkan atom Mo memerlukan kalor sebesar 598,0 kJ/mol untuk menguapkan atom-atomnya. Oleh karena itu, dengan kalor yang sama, oksida silikon yang terbentuk lebih mudah mengelupas dari pada oksida molybdenum.

Secara umum paduan TiAl yang diimplantasi dengan ion Mo mempunyai ketahanan oksidasi yang lebih baik dari pada paduan TiAl yang diimplantasi dengan ion $\mathrm{Si}$, karena paduan TiAl yang diimplantasi dengan ion Mo mempunyai laju oksidasi yang lebih lambat dan umur pemakaian yang lebih lama dibandingkan dengan paduan $\mathrm{TiAl}$ yang diimplantasi dengan ion $\mathrm{Si}$.

Penambahan ion Si pada paduan TiAl yang telah diimplantasi dengan ion Mo dengan dosis ion $4,5 \times 10^{15}$ ion $/ \mathrm{cm}^{2}$ cenderung menurunkan ketahanan oksidasinya tetapi efek ketahanan oksidasinya masih lebih baik dari pada paduan TiAl yang tidak diimplantasi.

Penambahan ion Mo pada paduan TiAl yang telah diimplantasi dengan ion Si pada dosis ion 4,5 x $10^{15} \mathrm{ion} / \mathrm{cm}^{2}$, ketahanan oksidasinya lebih baik dari pada paduan terner TiAl-Si dan paduan biner TiAl yang tidak diimplantasi, khususnya pada paduan terner TiAl-Si yang diimplantasi dengan ion Mo pada dosis ion $1,5 \times 10^{15} \mathrm{ion} / \mathrm{cm}^{2}$, karena pada dosis ini laju oksidasinya paling lambat sehingga diharapkan mampu mengendalikan oksidasi.

\section{KESIMPULAN}

Berdasarkan hasil penelitian yang telah dilakukan dapat diambil kesimpulan sebagai berikut :

1. Implantasi elemen reaktif Si pada paduan biner TiAl serta implantasi elemen reaktif Mo pada paduan biner TiAl dan terner TiAl-Si mampu meningkatkan ketahanan oksidasi paduan tersebut selama siklus termal pada suhu $800{ }^{0} \mathrm{C}$. Sedangkan implantasi elemen $\mathrm{Si}$ pada paduan TiAl-Mo cenderung menurunkan laju oksidasi.

2. Kondisi optimum dari implantasi ion Si dan Mo untuk meningkatkan ketahanan oksidasi paduan biner TiAl selama siklus termal pada suhu $800{ }^{0} \mathrm{C}$ dicapai pada dosis ion $4,5 \times 10^{15}$ ion $/ \mathrm{cm}^{2}$ untuk ion $\mathrm{Si}$ 
dan $1,5 \times 10^{15}$ ion/ $/ \mathrm{cm}^{2}$ untuk ion Mo. Sedangkan kondisi optimum dari implantasi ion Mo untuk meningkatkan ketahanan oksidasi paduan terner TiAl-Si dicapai pada dosis ion $1,5 \times 10^{15} \mathrm{ion} / \mathrm{cm}^{2}$.

\section{UCAPAN TERIMA KASIH}

Pada kesempatan ini Penulis mengucapkan terima kasih kepada Bapak Al. Sunarto dan Bapak J. Karmadi, yang telah membantu dalam penelitian ini.

\section{DAFTAR PUSTAKA}

1. MAYER, J., QUADAKKERS, W.J., UNTORO, P., Improvement of High-Temperature Corrosion Resistance of Titanium Aluminides”, DFG/BMZ Programme on Research Co-operation with Developing Countries)

2. STRAWBRIDGE,A. and HOU,P.Y., "The Role of Reactive Elements in Oxide Scale Adhesion", Materials at High Temperatures Volume 12 Numbers 2-3 (1994) 177-181
3. ES-SOUNI,M., BARTELS,A., WAGNER,R., Creep Behaviour of a Fully Transformed Near $\gamma$-TiAl Alloy Ti-48Al-2Cr, Acta Metall mater, Vol. 43, No. 1, pp. 153-161 (1995)

4. SVENKNIPPSCHEER and GEORGE FROMMEYER, Intermettalic TiAl (Cr,Mo,Si) Alloys for Light Weight Engine Parts Structure, Properties and Application, Advanced Enginnering Materials, Vol. 1, No. 3-4, (1999)

5. HORNAUER, U., et al., Microstructure and Oxidation Kinetics of Intermetallic TiAl after Si- and Mo- Ion Implantation, Surface and Coatings Technology, 128-129, (2000),418-422

6. VARMA, S.K., ALVARO CHAN, and MAHAPATRA, Static and Cyclic oxidation of Ti-44Al and Ti-44Al-xNb alloys, Oxidation of Metals, Vol. 55, No. 5/6, (2001)

7. RYSSEL, H., and RUGE, I., Ion Implantation, John Wiley, Inc., New York, (1986

8. ASWORTH, V., Ion Implantation into Metals, Pergamon Press, (1982). 